\title{
Meat Quality, Blood Profile, and Fecal Ammonia Concentration of Broiler Supplemented with Liquid Smoke
}

\author{
F. Yosi* \& S. Sandi \\ Department of Animal Science, Faculty of Agriculture, University of Sriwijaya \\ Research Center for Sub-optimal Lands (PUR-PLSO), University of Sriwijaya \\ Jln. Palembang-Prabumulih KM.32, Indralaya, Ogan Ilir, South Sumatera, Indonesia 30662 \\ (Received 24-02-2014; Reviewed 10-04-2014; Accepted 03-07-2014)
}

\begin{abstract}
Liquid smoke is one of the feed additive that can be given to animals. The aim of the study was to determine the influence of liquid smoke given through drinking water on meat quality and production of fecal ammonia in broiler. Variables observed were meat $\mathrm{pH}$, water holding capacity, cooking loss, the tensile strength of meat, cut off strength of meat, blood urea nitrogen and creatinine concentrations, and fecal ammonia. The experiment was assigned in a completely randomized design with 5 treatments, and 4 equal replicates. The treatments tested were symbolized as R0, R1, R2, R3, and R4, based on the level of liquid smoke added into drinking water $(\mathrm{v} / \mathrm{v})$ namely, $0 \%, 0.25 \%, 0.50 \%, 0.75 \%$, and $1.00 \%$, respectively. The data were subjected to analysis of variance, and continued to Duncan's multiple range test to determine the difference between treatment mean values at $5 \%$ probability. The results indicated that addition of liquid smoke up to $1 \%$ did not affect the meat $\mathrm{pH}$, water holding capacity, cooking loss, the tensile strength of meat, blood urea nitrogen, and creatinine content, but it decreased the cut off strength of meat and fecal ammonia. It was concluded that an optimal dose of granting liquid smoke through drinking water was $1 \%$.
\end{abstract}

Key words: liquid smoke, broiler, meat quality, fecal ammonia

\section{ABSTRAK}

Asap cair adalah salah satu pakan aditif yang dapat diberikan pada ternak. Penelitian ini bertujuan untuk menentukan pengaruh pemberian asap cair melalui air minum pada kualitas daging dan produksi gas amonia pada ayam broiler. Peubah yang diamati antara lain $\mathrm{pH}$ daging, daya ikat air, daya tarik daging, susut masak, daya putus daging, nitrogen urea darah, kreatinin, dan konsentrasi amonia pada feses. Rancangan penelitian yang digunakan adalah rancangan acak lengkap (RAL) yang terdiri atas 5 perlakuan dan 4 ulangan. Perlakuan yang diberikan adalah penambahan asap cair dalam air minum dengan jumlah masing-masing $0 ; 0,25 ; 0,50 ; 0,75 ;$ dan $1,00 \%$ (v/v). Data dianalisis dengan sidik ragam. Perbedaan antarperlakuan dianalisis dengan uji jarak berganda Duncan pada taraf $5 \%$. Hasil penelitian menunjukkan bahwa penambahan asap cair dalam air minum sampai taraf $1 \%$ tidak berpe-ngaruh terhadap nilai $\mathrm{pH}$ daging, daya ikat air, daya tarik daging, susut masak, blood urea nitrogen, dan kandungan kreatinin, akan tetapi dapat menurunkan nilai daya putus daging dan produksi gas amoniak. Hal ini dapat disimpulkan bahwa dosis pemberian asap cair yang optimal adalah $1 \%$.

Kata kunci: asap cair, broiler, gas amonia, kualitas daging

\section{INTRODUCTION}

Additive is one of the feed ingredients that commonly used in the formulation of animal feed, since it has a very important role in increasing the productivity and health of poultry (Sofyan et al., 2010). One of the

*Corresponding author:

E-mail: fitrayosi@unsri.ac.id/fitra_214@yahoo.co.id potential additional feed given to livestock is liquid smoke (Wang et al., 2012). Liquid smoke is a mixture of aqueous dispersion of wood smoke in the water created by the process of condensation of wood smoke resulted from pyrolysis at a temperature of $600-900{ }^{\circ} \mathrm{C}$ (Wang et $a l ., 2012$ ). Liquid smoke is generated from wood that is roughly comprised of $50 \%$ cellulose, $25 \%$ hemicellulose, and 25\% lignins (Simko, 2005). Liquid smoke contains carboxyl acid compounds produced by the decomposition of hemicellulose during pyrolysis (Akakabe et al., 
2006). Liquid smoke also contains more than 200 types of organic compounds, such as acetic acid, phenol, alcon, alcohol, aldehyde, and others (Nomura, 2004; Wang et al., 2012). Mu et al. (2004) stated that among 200 chemical components presence in the liquid smoke, acetic acid, which reach almost $60 \%$, was the largest chemical component

It was reported that phenolic and carbonyl compounds of liquid smoke can establish the specific meat flavor (Arizona et al., 2010; Lingbeck et al., 2014). The constituents of phenolic compounds are siringol, guaiacol, 4-metilguaiacol, 4 metilsiringol and eugenol. Liquid smoke was also reported could increase the physical quality of meat. Arizona et al. (2011) showed that the higher level of additional liquid smoke increased the water holding capacity (WHC). WHC is the ability of fresh meat to retain its own water (Pearce et al., 2011). Improvement of WHC was also indicated by the report of Abustam \& Ali (2011), that the use of liquid smoke could increase the functional properties of meat, especially $\mathrm{pH}$ and water holding capacity.

It is known that levels of blood urea nitrogen (BUN) and creatinine can be used as an indicator of kidney function to describe the balance between the formation of urea and protein catabolism and urea excretion or as an estimate of the rate of glomerulus filtration (Scholz, 2005). Blood level of nitrogen can be measured by using analysis of urease enzyme, while creatinine was determined by using reactant of picric acid or creatinine enzyme of aminohydrolases (Kaplan \& Pesce, 2009). In addition, liquid smoke can also decrease the release of total Kjeldahl nitrogen (TKN) during the process of putrefaction of excreta (Asada et al., 2006; Chen et al., 2010) that finally reduced the production of fecal ammonia. The above described condition is necessary to be evaluated since high ammonia concentration could decrease livestock performance, and decreased feed efficiency as well as caused respiratory problems (Pescatore et al., 2005; Yurizal, 2012). The present study was conducted to evaluate the effect of liquid smoke dissolved in drinking water on meat quality, BUN, creatinine, and fecal ammonia concentration in broiler chicken.

\section{MATERIALS AND METHODS}

\section{Birds, Feed, and Cage}

A total of 120 unsexed Cobb broiler chicks bought from commercial poultry in South Sumatera, Indonesia were used in the current study. Chicks were fed commercial starter diet (crumble) from 7-21 d of age, and commercial finisher diet (pellet) from 22-35 d of age. The commercial feed was purchased from poultry shop. The nutritional contents of the feed used in the present study were shown in Table 1. Liquid smoke was obtained from Badja Baru factory located in Palembang, South Sumatera. The content of compounds in liquid smoke used in this study was shown in Table 2. All chicks were reared in a conventional open-sided house by allocating into 20 units of cage of $70 \times 70 \times 60 \mathrm{~cm}(1 \times \mathrm{w} \times \mathrm{h})$ in size with 6 birds each.

\section{Experimental Procedure}

Liquid smoke was provided through drinking water and given every day from 1-35 d of age. The treatments tested were R0, R1, R2, R3, and R4. The first symbolized as R0 function as a control (without added liquid smoke), while the other four namely, R1, R2, R3, and R4 were treatment with the addition of liquid smoke into drinking water with the level of $0.25 \%, 0.50 \%, 0.75 \%$, and $1.00 \%$, respectively. Level of $0.25 \%$ was equal to 2.5 $\mathrm{mL}$ liquid smoke per one liter water.

Table 1. Nutrient contents of experimental diet (dry matter basis)

\begin{tabular}{lcc}
\hline Nutrient contents & $\begin{array}{c}\text { Starter diet } \\
(7-21 \text { d of age })\end{array}$ & $\begin{array}{c}\text { Finisher diet } \\
(22-35 \text { d of age })\end{array}$ \\
\hline Crude protein (\%) & 21 & 19 \\
ME (Kcal/kg) & 3000 & 3100 \\
Fat (\%) & 4 & 4 \\
Fiber (\%) & 5 & 5.5 \\
Ash (\%) & 6 & 6 \\
Calcium (\%) & 0.9 & 0.9 \\
Phosphorus (\%) & 0.7 & 0.7 \\
\hline
\end{tabular}

Source : PT. Japfa Comfeed

Table 2. Compund contents of liquid smoke used in this study

\begin{tabular}{|c|c|c|}
\hline Compounds & $\begin{array}{l}\text { Time of retention } \\
\text { (minute) }\end{array}$ & $\%$ \\
\hline 1-Methylindane & 3.554 & 0.66 \\
\hline 1,3-Dimethylborazine & 3.628 & 0.43 \\
\hline Silane-Phenyl-Benzene & 3.674 & 0.39 \\
\hline Phenol, 4-amino & 3.746 & 3.58 \\
\hline 1,3-Dimethylborazine & 3.891 & 0.74 \\
\hline Cevane-3, epoxy, 3-acetate & 4.115 & 5.72 \\
\hline Phenol, 2-Methoxy & 4.286 & 5.65 \\
\hline $\begin{array}{l}\text { 2-Isopropenylthiophene } \\
\text { Cyclohexane } \\
\text { 4-Methoxy-2 }\end{array}$ & 4.349 & 3.17 \\
\hline Cyclohexane & 4.504 & 2.57 \\
\hline Phenol & 4.589 & 3.73 \\
\hline 3-fluoro-o-xylene & 4.801 & 4.95 \\
\hline Imidazole-5-carboxylic acid & 5.516 & 2.03 \\
\hline 1,4-Benzenedimethanol & 6.277 & 1.15 \\
\hline Phenol, 2-methoxy-4-methyl & 6.535 & 3.11 \\
\hline Cyclobutene & 8.086 & 13.16 \\
\hline Pentalenone & 8.732 & 6.26 \\
\hline 1,2-Benzenediol & 8.869 & 1.85 \\
\hline 1-pentalenone & 8.95 & 6.26 \\
\hline Phenol & 11.313 & 16.3 \\
\hline Benzoic Acid & 13.911 & 6.65 \\
\hline $\begin{array}{l}\text { Benzene, 1,2,5-trimethoxy-3- } \\
\text { methyl } \\
\text { 3-Furancarboxylic acid }\end{array}$ & 15.965 & 2.91 \\
\hline $\begin{array}{l}\text { 2,5-dihydroxy-4-isopropyl-2,4,6-cy } \\
\text { Benzeneacetic acid }\end{array}$ & 16.285 & 1.89 \\
\hline
\end{tabular}

Note: Sample was analyzed in Lab. of Regional Health, Central Jakarta. 


\section{Variables Measured}

At the end of experiment (35 day of age) one bird from each replication was randomly decapitated for meat sampling. The breast muscles (without skin) were used for physical meat quality analysis $(\mathrm{pH}$, cooking loss, water holding capacity, tensile strength, and cut off strength). The meat samples were analyzed about 1-2 $\mathrm{h}$ after decapitation.

pH value. Meat $\mathrm{pH}$ was measured according to Soewedo (1994). Meat samples were mashed with meat grinder, and $2 \mathrm{~g}$ sample was diluted with $18 \mathrm{~mL}$ of distilled water and stirred until homogen and then filtered. The filtrate samples were measured with a $\mathrm{pH}$ meter.

Cooking loss. Cooking loss was determined according to Nikmaram et al. (2011). Meat sample (20 g) was placed in polyethylene plastic, then sealed with vaccum pack, and heated in a water bath at 80 .C for $30 \mathrm{~min}$. After being cooked, samples were cooled at room temperature, dried surface with filter paper, reweighed by using an analytical balance (Metler AE100-0.001), and the cooking loss was calculated from difference between raw and cooked weights.

Water holding capacity. Water holding capacity (WHC) was determined according to Hamm method (1960). Meat sample $(0.3 \mathrm{~g})$ was put on Whatman 41 filter paper and placed between two metal plates with a pressure load of $35 \mathrm{~kg}$ for $5 \mathrm{~min}$ until wet area was formed on the filter paper. Wet area was calculated by subtracting the total area (wide outer ring) with the area covered meat samples (circle area).

The strength of tensile and cut off of meat. The strength of tensile and cutoff meat was measured by the method of Person \& Dutson (Murtini \& Qomarudin, 2003). This procedure used universal testing instrument merk Lloyd in units of newton. Samples were cut into a cube with a size of $1 \times 1 \times 1 \mathrm{~cm}$. The samples were laid under a repressor and then the instrument was executed.

Blood urea nitrogen and creatinine. Blood urea nitrogen and creatinine were measured by using serum sample. At the end of the study, around $5 \mathrm{~mL}$ blood sample was taken from the jugular vein and immediately pro- cessed at the laboratory of clinical pathology (Salasia \& Khusnan, 2001).

Ammonia concentration. Ammonia concentration was measured by the method of micro diffusion Conway. About $1 \mathrm{~mL}$ of supernatant was placed on one side of the Conway cups septum placed obliquely toward the septum. The Conway cup was formerly smeared with vaseline on both surfaces. The other side was filled with $1 \mathrm{~mL}$ of saturated aqueous $\mathrm{Na}_{2} \mathrm{CO}_{3}$, while the central part was filled with $1 \mathrm{~mL}$ of boric acid. The Conway cup was closed until airtight and shaken so that the supernatant and $\mathrm{Na}_{2} \mathrm{CO}_{3}$ were well blended. The Conway cup was settled for $24 \mathrm{~h}$ at room temperature. Ammonia bound with boric acid was titrated with $\mathrm{H}_{2} \mathrm{SO}_{4} 0.005 \mathrm{~N}$ until the color became reddish.

\section{Experimental Design and Statistical Analysis}

The experiment was assigned in a completely randomized design with 5 treatments (as described in the Section of Experimental Procedure) and 4 equal replications ( 6 birds each). The data were subjected to analysis of variance, and the differences between the treatments were analyzed by Duncan's multiple range test (Stell \& Torrie, 1980).

\section{RESULTS AND DISCUSSION}

\section{Meat Quality}

The result showed that the use of liquid smoke through drinking water did not affect the meat $\mathrm{pH}$. The average of meat $\mathrm{pH}$ was 5.83 (Table 3). The value of the meat $\mathrm{pH}$ on this study was lower than normal $\mathrm{pH}$ of broiler meat. Van Laack et al. (2000) stated that the normal $\mathrm{pH}$ value of broiler chicken meat was ranged between 5.96 and 6.07. Suradi (2008) stated that the average of early $\mathrm{pH}$ of the breast meat on broiler chicken was 6.31, and then it declined after postmortem and reached the values of 5.96-5.82 at 6-10 h. The nonsignificant effects of treatment on meat $\mathrm{pH}$ was possibly due to the low total organic acid content of liquid smoke, i.e. 19.2\% (Table 2). In this study, organic acids contained in liquid smoke were acetic acid, carboxylic acid, benzoic acid, and furancarboxylic acid. The organic acid has ability to inhibit the process of rigor mortis on meat so that it

Table 3. Quality of broiler chicken meat aged 5 weeks and supplemented with various levels of liquid smoke in drinking water

\begin{tabular}{|c|c|c|c|c|c|}
\hline \multirow{2}{*}{ Parameters } & \multicolumn{5}{|c|}{ Treatments } \\
\hline & R0 & R1 & R2 & R3 & R4 \\
\hline $\mathrm{pH}$ & $5.76 \pm 0.14$ & $5.73 \pm 0.19$ & $5.92 \pm 0.04$ & $5.91 \pm 0.03$ & $5.82 \pm 0.17$ \\
\hline Water holding capacity (\%) & $22.87 \pm 1.36$ & $22.43 \pm 2.30$ & $18.93 \pm 4.66$ & $18.80 \pm 3.47$ & $22.87 \pm 1.76$ \\
\hline Tensile strength (Newton) & $3.60 \pm 0.36$ & $3.67 \pm 2.72$ & $1.73 \pm 0.12$ & $3.57 \pm 1.00$ & $4.47 \pm 4.07$ \\
\hline Cooking loss (\%) & $34.75 \pm 3.21$ & $35.30 \pm 2.16$ & $28.83 \pm 4.69$ & $30.81 \pm 5.41$ & $27.97 \pm 6.24$ \\
\hline Cut off strength (Newton) & $0.94 \pm 0.27^{a}$ & $0.83 \pm 0.14^{\mathrm{ab}}$ & $0.70 \pm 0.15^{\mathrm{ab}}$ & $0.55 \pm 0.04^{\mathrm{bc}}$ & $0.33 \pm 0.09^{c}$ \\
\hline
\end{tabular}

Note: Means in the same row with different superscripts differ significantly $(\mathrm{P}<0.05)$. R0= drinking water without added liquid smoke (control), R1= drinking water + liquid smoke $0.25 \%$, R2 = drinking water + liquid smoke $0.5 \%$, R3= drinking water + liquid smoke $0.75 \%$, $\mathrm{R} 4=\mathrm{drinking}$ water + liquid smoke $1.00 \%$. 
maintains the $\mathrm{pH}$ of meat remains high. Abustam \& Ali (2011) stated that the high acid content in the liquid smoke could slow or delay the process of rigor mortis, so a high meat $\mathrm{pH}$ can be retained. In line with this, Suradi (2008) stated that the lower the $\mathrm{pH}$ of meat, the quality of meat will also be getting low.

The result showed that the use of liquid smoke through drinking water did not affect the WHC of meat. The average of WHC of meat was $21.58 \%$ (Table 3). Soeparno (2005) stated that WHC of broiler meat at the age of 6 and 7 weeks was $22.19 \%$ to $28.54 \%$. There were a correlation between WHC and meat $\mathrm{pH}$ (Tang et al., 2007), whereas the decrease in meat $\mathrm{pH}$ results in the decrease in WHC (Bee et al., 2007; Swatland, 2008; Jung et al., 2010). Alvarado \& McKee (2007) stated that one of the factors that affected the WHC of meat was acidity/pH. The organic acids contained in liquid smoke could make a bonding strips of myofibril became looser (Abustam \& Ali, 2011). This looser binding then forms the empty space that is eventually filled by water so that the WHC of meat increased. Abustam \& Ali (2011) reported that the more liquid smoke used, the WHC of meat was getting low. Due to the meat $\mathrm{pH}$ in this study was not significantly different, so that the WHC of meat was not also different. Huff-Lonergan \& Lonergan (2005) reported that WHC was also influenced by postmortem proteolysis.

The result showed that the used of liquid smoke through drinking water did not affect the tensile strength of meat. The average of tensile strength of meat in this study was 3.41 Newton (Table 3). There was a positive correlation between the tensile strength of meat and meat pH. Min \& Ahn (2005); Ke et al. (2009) stated that the $\mathrm{pH}$ of meat was one of the indicators that determined the value of tenderness, where one of them was reflected by the value of tensile strength of meat. Murtini \& Qomarudin (2003) stated that when the force required to pull the meat was lower, the tenderness of the meat was increased. In another word, the low value of tensile strength will improve the quality of meat (Utami et al., 2011).

The result showed that the used of liquid smoke through drinking water did not affect the cooking loss of meat. The average of cooking loss of meat in this study was $31.35 \%$ (Table 3). Soeparno (2005) stated that cooking loss of broiler meat at the age of 6 and 7 weeks was $24.89 \%$ to $34.57 \%$. The cooking loss of meat was correlated with meat $\mathrm{pH}$. If the meat had a high $\mathrm{pH}$, the cooking loss of meat would be high too. The value of cooking loss was used to predict the amount of fluid in cooked meats (Soeparno, 2005). Suradi (2008) reported that the meat with a low cooking loss had a physical quality that was relatively better than the meat with a high cooking loss. This result was related to the lower nutrients lost during cooking.

The cut off strength of broiler meat was significantly $(\mathrm{P}<0.05)$ affected by treatments. The highest cut off strength of meat was found in group of R0 (Table 3 ). The use of liquid smoke as much as $1 \%$ through drinking water $(\mathrm{R} 4)$ significantly $(\mathrm{P}<0.05)$ decreased cut off strength of meat to the lowest value (0.33 Newton) and it was significantly different as compared to R0, R1, R2, and R3. The use of liquid smoke in R4 might achieve an ideal condition for cut off strength of meat. Prayitno et al. (2010) stated that cut off strength of meat was affected by meat $\mathrm{pH}$ and WHC. In this study, the meat $\mathrm{pH}$ and WHC were not significantly affected by liquid smoke but it significantly affected the cut off strength of meat. The difference was possibly due to the time while measuring the cut off strength, whereas the measurement was conducted in the last session. It finally affected the value of meat $\mathrm{pH}$. In the beginning, meat $\mathrm{pH}$ was still high and it gradually declined with the increased duration before measurement. This condition was caused by glycolysis process that produced lactic acid in the meat (Park et al., 2010). The decline in the value of the cut off strength of meat is one of the indicators of tenderness. Utami et al. (2011) reported that the lower the cut off strength of meat, then the higher the tenderness of meat.

\section{Blood Urea Nitrogen, Creatinine, and Ammonia}

The result showed that the used of liquid smoke through drinking water did not affect the BUN and creatinine. The average of BUN and creatinine concentrations were $6.76 \mathrm{mg} / \mathrm{dL}$ and $0.17 \mathrm{mg} / \mathrm{dL}$, respectively (Table 4). The same results also shown from the research of Yan et al. (2012), that supplementation of liquid smoke did not show the significant effect on creatinine. This study indicated that the use of liquid smoke until 1\% through drinking water was still safe to be consumed by broiler chicken and did not disturb the kidney function. Scholz (2005) stated that the levels of BUN and creatinine were very sensitive parameter to describe the function of kidneys. If the glomerulus cells on kidney damaged, the rate of glomerulus filtration became declining. This would finally cause urea and creatinine accumulation in the plasma. In line with this, Wahjuni \& Bijanti (2006)

Table 4. Blood urea nitrogen, creatinine, and ammonia concentration in broiler supplemented with various levels of liquid smoke in drinking water

\begin{tabular}{lccccc}
\hline \multirow{2}{*}{\multicolumn{1}{c}{ Parameters }} & \multicolumn{4}{c}{ Treatments } \\
\cline { 2 - 6 } & R0 & R1 & R2 & R3 & R4 \\
\hline Blood Urea Nitrogen (BUN) (mg/dL) & $6.79 \pm 1.42$ & $7.20 \pm 1.87$ & $5.85 \pm 2.53$ & $7.61 \pm 1.33$ & $6.35 \pm 1.07$ \\
Creatinine (mg/dL) & $0.23 \pm 0.23$ & $0.07 \pm 0.05$ & $0.14 \pm 0.05$ & $0.12 \pm 0.07$ & $0.27 \pm 0.02$ \\
Ammonia concentration (ppm) & $115.25 \pm 10.03^{\mathrm{a}}$ & $81.71 \pm 3.90^{\mathrm{b}}$ & $76.78 \pm 2.74^{\mathrm{b}}$ & $65.94 \pm 4.43^{\mathrm{c}}$ & $60.62 \pm 3.71^{\mathrm{e}}$ \\
\hline
\end{tabular}

Note: Means in the same row with different superscripts differ significantly $(\mathrm{P}<0.05)$. R0= drinking water without added liquid smoke (control), R1= drinking water + liquid smoke $0.25 \%, \mathrm{R} 2=$ drinking water + liquid smoke $0.5 \%$, R3= drinking water + liquid smoke $0.75 \%$, $\mathrm{R} 4=\mathrm{drinking}$ water + liquid smoke $1.00 \%$. 
also stated that the increased concentration of creatinine in the blood indicated the kidney function was getting corrupted. There were also a relationship between protein intake and creatinine (Araujo et al., 2006). Although the protein intake affected creatinine, its influence was not direct because creatinine was synthesized from creatine using essential amino acids, arginine and glycine, as precursors.

The use of liquid smoke through drinking water significantly $(\mathrm{P}<0.05)$ affected the amount of ammonia. This results showed that the amount of ammonia given by the treatment of $\mathrm{R} 0$ was the highest $(\mathrm{P}<0.05)$ among the other treatments. The amount of ammonia produced between treatment R1 and R2 did not differ significantly, but higher $(\mathrm{P}<0.05)$ than the treatment of $\mathrm{R} 3$ and $\mathrm{R} 4$, and lower $(\mathrm{P}<0.05)$ than treatment of $\mathrm{R} 0$. Meanwhile, the amount of ammonia generated between the treatment of R3 and R4 were not significantly different. Based on Table 4, the highest amount of ammonia produced was in the treatment of R0 (without the addition of liquid smoke through drinking water), which was 115.25 ppm.

The high production of ammonia in excreta showed that the process of proteins digestion in feed did not run optimally. Hendalia et al. (2012) stated that decreased digestibility of feed protein caused the decreased nitrogen absorption and increased nitrogen excretion through excreta in the form of uric acid, and it would finally be transformed into ammonia by bacteria. Based on this study, supplementation of liquid smoke through drinking water could increase the digestion process of the feed proteins in the digestive tract. This was closely related to the role of chemical compounds in the liquid smoke, one is an organic acid. Chen et al. (2010) and Yan et al. (2012) stated that the organic acids in liquid smoke could reduce the release of total kjeldahl nitrogen (TKN) during the process of decaying of excreta, so that it finally could reduce emissions of gas by livestock. In line with this, Asada et al. (2006) also reported that with the granting of bamboo vinegar, it make the release of TKN became more effective.

The amount of ammonia decreased with the supplementation of liquid smoke through drinking water. This result is in line with result reported by Yan et al. (2012) that supplementation of bamboo vinegar could decrease ammonia in pig feces. North \& Bell (1990) stated that the amount of ammonia inside the cage should not exceed $25 \mathrm{ppm}$. If the ammonia levels inside the cage exceed 25 ppm, the productivity of chicken would decrease and it could cause the death in chickens if the level of ammonia reached $0.05 \%$ or $500 \mathrm{ppm}$. In this study, the level of ammonia produced was gradually declined with the increased level of liquid smoke supplementation. This technique was good for chickens to keep them in health.

\section{CONCLUSION}

The optimal level of liquid smoke supplementation through drinking water was $1 \%$, because it could decrease the cut off strength of meat and production of fecal ammonia. The value of meat $\mathrm{pH}, \mathrm{WHC}$, cooking loss, the tensile strength of meat, BUN, and creatinine content were not affected by the liquid smoke supplementation.

\section{ACKNOWLEDGEMENT}

The authors greatly acknowledge PT. Badja Baru in South Sumatera for full financial support of this research.

\section{REFERENCES}

Abustam, E. \& H. M. Ali. 2011. The effects of muscle types and levels of liquid smoke on water holding capacity and shear force values of pre rigor Bali beef. http://repository.unhas. ac.id/handle/123456789/480. [4 October 2011]

Akakabe, Y., Y. Tamura, S. Iwamoto, M. Takabayashi, \& T. Nyuugaku. 2006. Volatile organic compounds with characteristic odor in bamboo vinegar. Biosci. Biotechnol. Biochem. 70: 2797-2799. http://dx.doi.org/10.1271/bbb.60317

Alvarado, C. \& S. McKee. 2007. Marination to improve functional properties and safety of poultry meat. J. Appl. Poult. Res. 16:113-120. http://dx.doi.org/10.1093/japr/16.1.113

Araujo, I. C., M. A. Kamimura, S. A. Draibe, M. E. F. Canziani, S. R. Manfredi, C. M. Avesani, R. Sesso, \& L. Cuppari. 2006. Nutrititonal parameters and mortality in incident hemosialysis patients. J. Ren. Nutr. 16: 27-35. http://dx.doi. org/10.1053/j.jrn.2005.10.003

Arizona, R., E. Suryanto, \& Y. Erwanto. 2011. The effect of canary shell liquid smoke concentration and storage time on chemical and physical quality of beef. Buletin Peternakan 35: 50-56.

Asada, T., T. Ohkubo, K. Kawata, \& K. Oikawa. 2006. Ammonia adsorption on bamboo charcoal with acid treatment. J. Health Sci. 52: 585-589. http://dx.doi.org/10.1248/ jhs. 52.585

Bee, G., A. L. Anderson, S. M. Lonergan, \& E. Huff-Lonergan. 2007. Rate and extent of $\mathrm{pH}$ decline affect proteolysis of cytoskeletal proteins and water-holding capacity in pork. Meat Sci. 76: 359-365. http://dx.doi.org/10.1016/ j.meatsci.2006.12.004

Chen, Y. X., X. D. Huang, Z.Y. Han, X. Huang, B. Hu, D. Z. Shi, \& W. X. Wu. 2010. Effects of bamboo charcoal and bamboo vinegar on nitrogen conservation and heavy metals immobility during pig manure composting. Chemosphere. 78: 1177-1181. http://dx.doi.org/10.1016/j.chemosphere.2009.1 2.029

Jung, S., J. H. Choe, B. Kim, H. Yun, Z. A. Kruk, \& C. Jo. 2010. Effect of dietary mixture of gallic acid and linoleic acid on antioxidative potential and quality of breast meat from broilers. Meat Sci. 86: 520-526. http://dx.doi.org/10.1016/ j.meatsci.2010.06.007

Kaplan, L. A. \& A. J. Pesce. 2009. Clinical Chemistry: Theory, Analysis, and Correlation. $5^{\text {th }}$ ed. St. Louis, MO, Mosby.

Ke, S., Y. Huang, E. A. Decker, \& H. O. Hultin. 2009. Impact of citric acid on the tenderness, microstructure and oxidative stability of beef muscle. Meat Sci. 82: 113-118. http:// dx.doi.org/10.1016/j.meatsci.2008.12.010

Hendalia, A., F. Manin, Yusrizal, \& G. M. Nasution. 2012. The aplication of probiotik in increasing protein efficiency and reducing fecal ammonia in broiler chicken. Agrinak 2: 2935.

Huff-Lonergan, E. \& S. M. Lonergan. 2005. Mechanisms of water-holding capacity of meat: The role of postmortem biochemical and structural changes. Meat Sci. 71: 194-204. http://dx.doi.org/10.1016/j.meatsci.2005.04.022

Hamm, R. 1960. Biochemistry of meat hydration. Adv. Food Res. 10: 355-436. http://dx.doi.org/10.1016/S00652628(08)60141-X

Lingbeck, J. M., P. Cordero, C. A. O'Bryan, M. G. Johnson, S. C. Ricke, \& P. G. Crandall. 2014. Functionality of liquid smoke as an all-natural antimicrobial in food preserva- 
tion. Meat Sci. 97: 197-206. http://dx.doi.org/10.1016/ j.meatsci.2014.02.003

Min, B. \& D. U. Ahn. 2005. Mechanism of lipid oxidation in meat and meat products - A review. Food Sci. Biotechnol. 14: 152-163.

Mu, J., T. Uehara, \& T. Furuno. 2004. Effect of bamboo vinegar on regulation of germination and radical growth of seed plants II: composition of Moso bamboo vinegar at different collection temperature and its effects. J. Wood Sci. 50: 470-476. http://dx.doi.org/10.1007/s10086-003-0586-y

Murtini, E. S. \& Qamaruddin. 2003. Meat tenderization using protease of Biduri Plant (Calotropis gigantea). Jurnal Teknologi dan Industri Pangan 14: 266-268.

Nikmaram, P., M. S. Yarman, \& Z. Emamjomeh. 2011. Effect of cooking methods on chemical composition, quality and cook loss ofcamel muscle (Longissimus dorsi) in comparison with veal. Afr. J. Biotech. 10: 10478-10483.

Nomura, R. 2004. Healthy Effects of Bamboo Vinegar. Nobunkyou Publication.

North, M. O. \& D. D. Bell. 1990. Commercial Chicken Production Manual. $4^{\text {th }}$ Ed. An Avi Book. Van Nostrand Reinhold, New York.

Park, K. M., A. B. Pramod, J. H. Kim, H. S. Choe, \& I. H. Hwang. 2010. Molecular and biological factors affecting skeletal muscle cells after slaughtering and their impact on meat quality: A mini review. J. Muscle Foods 21: 280-307. http://dx.doi.org/10.1111/j.1745-4573.2009.00182.x

Pearce, K. L., K. Rosenvold, H. J. Andersen, \& D. L. Hopkins. 2011. Water distribution and mobility in meat during the conversion of muscle to meat and ageing and the impacts on fresh meat quality attributes - A review. Meat Sci. 89: 111-124. http://dx.doi.org/10.1016/j.meatsci.2011.04.007

Pescatore, A. J., K. D. Casey, \& R. S. Gates. 2005. Ammonia emissions from broiler houses. J. Appl. Poult. Res. 14:635637. http://dx.doi.org/10.1093/japr/14.3.635

Prayitno, A. H., E. Suryanto, \& Zuprizal. 2010. Physical and sensory quality of meat of broiler chicken fed with the addition of virgin coconut oil waste. Buletin Peternakan 34: 55-63

Salasia, S. I. O. \& Khusnan. 2001. Study on the stability of blood sample. MKH. 17: 17 -21.

Scholz, M.C. 2005. Laboratory tests defined. PCRI. 8: 1-6.

Simko, P. 2005. Factors affecting elimination of polycyclic aromatic hydrocarbons from smoked meat foods and liquid smokeflavorings. Molecular Nutrition \& Food Research. 49: 637-647. http://dx.doi.org/10.1002/mnfr.200400091

Soeparno. 2005. Meat Science and Technology. Gadjah Mada University-Press, Yogyakarta, Indonesia
Soewedo, H. 1994. Theory and Technology of Meat. Gajah Mada University Press, Yogyakarta, Indonesia.

Sofyan, A., H. Julendra, E. Damayanti, B. Sutrisno, \& M. H. Wibowo. 2010. Performance and histopathology of broiler chicken infected by Salmonella pullorum and fed feed additive containing earth worm meal (Lumbricus rubellus). Med. Pet. 33:31-35

Steel, R. G. D. \& J. H. Torrie. 1980. Principles and Procedures of Statistics: A Biometrical Approach. 2nd Ed. McGraw-Hill Book Co., New York, NY.

Suradi, K. 2008. Change of physical character of broiler chicken meat post mortem during room temperature storage http://pustaka.unpad.ac.id/wp-content/uploads/2009/11/ perubahan_sifat_fisik_daging_ayam_broiler_post_mortem.pdf. [1 November 2013]

Swatland, H. J. 2008. How pH causes paleness of darkness in chicken breast meat. Meat Sci. 80: 396-400. http://dx.doi. org/10.1016/j.meatsci.2008.01.002

Tang, M. Y, Q. G. Ma, X. D. Chen, \& C. Ji. 2007. Effects of dietary metabolizable energy and lysine on carcass characteristics and meat quality in Arbor Acres broilers. AsianAust. J. Anim. Sci. 20: 1865-1873.

Utami, D. P., Pudjomartatmo, \& A. M. P. Nuhriawangsa. 2011. The use of bromelin from pineapple (Ananas comosus L. Merr) extract and different cooking time to increase meat quality of post production ducks. Sains Peternakan 9:8287.

Van Laack, R. L. J. M., C. H. Liu, M. O. Smith, \& H. D. Loveday. 2000. Characteristics of pale, soft, exudative broiler breast meat. Poultry Sci. 79:1057-1061. http://dx.doi.org/10.1093/ ps/79.7.1057

Wahjuni, R. S. \& R. Bijanti. 2006. Test of side effect of complete feed formula on renal and liver function of friesian holstein calf. Media Kedokteran Hewan 22: 174-179.

Wang, H. F., J. L. Wang, C. Wang, W. M. Zhang, J. X. Liu, \& B. Dai. 2012. Effect of bamboo vinegar as an antibiotic alternative on growth performance and fecal bacterial communities of weaned piglets. Livest. Sci. 144:173-180. http:// dx.doi.org/10.1016/j.livsci.2011.11.015

Yan, L., I. H. Kim, \& K. Huh. 2012. Influence of bamboo vinegar supplementation on growth performance, apparent total tract digestibility, blood characteristics, meat quality, fecal noxious gas content, and fecal microbial concentration in finishing pigs. Livest. Sci. 144: 240-246. http://dx.doi. org/10.1016/j.livsci.2011.11.020

Yusrizal, Y. 2012. Microbial and oligosaccharides treatments of feces and slurry in reducing ammonia of the poultry farm. Med. Pet. 35:152-156. http://dx.doi.org/10.5398/medpet.2012.35.3.152 